\title{
PROFIL DAN FAKTOR RISIKO KEMATIAN SEPSIS NEONATUS DI RSUD SUKADANA LAMPUNG TIMUR
}

\author{
Astri Pinilih ${ }^{1}$, Huminsa Ranto ${ }^{2}$ \\ ${ }^{1}$ Departemen IImu Anak, Fakultas Kedokteran, Universitas Malahayati \\ ${ }^{2}$ Prodi Kedokteran, Fakultas Kedokteran, Univertas Malahayati
}

\begin{abstract}
Profile and Risk Factors for Death of Neonatal Sepsis in RSUD Sukadana, East Lampung. Neonatal sepsis still becomes the major problem and causes mortality in neonates. The incidens of neonatal sepsis varies with unspecified clinical sign and rapid progressivity. The aim of this study was to determine the profile and factors associated with neonatal sepsis mortality in RSUD Sukadana East Lampung. A retrospective study was done in neonatology unit RSUD Sukadana East Lampung from July 2017 until August 2018. There were 55 neonates with sepsis as the subjects. Univariat analysis with the test of chi square and logistic regression multivariate analysis have been used and $p<005$ was considered statistically significant. The mortality rate of neonatal sepsis was $45 \%$. Most of mothers were between ages $18-35$ years (45\%), with single delivery $(87 \%)$. the average lenght of treatment for neonatal sepsis who died was 6.9 days. Asphyxia, low birth weight and early onset sepsis were associated with mortality neonatal sepsis RR 3.05 (95\%CI $0.04-0.49), p=0.002$; RR 1.72 (95\%CI 0.09-0.97), $p=0.043$ dan RR 2.51 (95\%CI 0.07-0.68), $p=0.009$. Asphyxia, low birth weight and early onset sepsis were significantly associated with mortality neonatal sepsis
\end{abstract}

Keywords: sepsis, neonatal, mortality, factors

\begin{abstract}
Abstrak: Profil dan Faktor Risiko Kematian Sepsis Neonatus Di RSUD Sukadana Lampung Timur. Sepsis neonatus masih merupakan masalah utama dan penyebab kematian pada neonatus, terutama di negara-negara berkembang. Insiden sepsis neonatus bervariasi dengan gejala klinis yang tidak khas dan progresivitas yang cepat. Tujuan penelitian ini adalah mengetahui profil dan faktor risiko kematian pada neonatus yang mengalami sepsis di RSUD Sukadana Lampung Timur. Penelitian restreospektif dilakukan di ruang perawatan neonatologi RSUD Sukadana Lampung Timur dari Juli 2017 hingga Agustus 2018. Terdapat 55 bayi dengan sepsis neonatus yang dilibatkan sebagai subyek penelitian. Analisis univariat dengan kai kuadrat, analisis multivariat dengan regresi logistik dan nilai $\mathrm{p}<0,05$ dianggap bermakna. Hasil penelitian berupa tingkat kematian sepsis neonatus adalah $45 \%$. Sebagian besar ibu berusia antara $18-35$ tahun $(45 \%)$ dengan persalinan tunggal merupakan jumlah persalinan terbanyak (87\%). Rerata lama perawatan bayi sepsis neonatus yang meninggal adalah 6,9 hari. Asfiksia, berat lahir rendah dan awitan sepsis dini secara bermakna berkaitan dengan kematian pada sepsis neonatus RR 3,05 (95\%CI 0,04-0,49), $p=0,002$; RR 1,72 $(95 \%$ CI $0,09-0,97), p=0,043$ dan RR 2,51 (95\%CI 0,07-0,68), $p=0,009$. Kesimpulan dari penelitian ini yaitu Asfiksia, berat lahir rendah dan awitan sepsis dini secara bermakna berkaitan dengan kematian pada sepsis neonatus.
\end{abstract}

Kata kunci: sepsis, neonatus, mortalitas, faktor

\section{PENDAHULUAN}

salah sepsis neonatus merupakan kematian pada neonatus. Kurang lebih $20 \%$ neonatus menderita sepsis dan hal ini menyebabkan 30\%-50\% total kematian neonatus pada negara berkembang (Jian, et al., 2003) World Health Organization (WHO) melaporkan case fatality rate yang 
tinggi (40\%) pada kasus sepsis neonatus. Hal tersebut terjadi karena banyak faktor resiko infeksi pada masa perinatal yang belum dapat dicegah dan ditanggulangi (Jumah dan Hasan, 2007).

Di Negara berkembang, kematian bayi karena sepsis neonatus sekitar 34 per 1000 kelahiran hidup, yang terjadi terutama di minggu pertama kehidupan, sementara di Negara maju 5 per 1000 kelahiran hidup (Ayoniyi, dkk., 2009). Penelitian di rumah sakit Cipto Mangunkusumo Jakarta pada tahun 2005, didapatkan insidensi sepsis neonatus $13,68 \%$ dari semua kelahiran hidup dengan angka kematian 14,18\% (Rohsiswatmo, 2005).

Sepsis neonatorum merupakan istilah yang sering digunakan untuk mendeskripsikan respons sistemik terhadap infeksi pada bayi baru lahir. Sepsis neonatal adalah sindrom klinik penyakit sistemik, disertai bakteremia yang terjadi pada bayi dalam satu bulan pertama kehidupan. Sepsis neonatorum biasa diartikan sebagai gejala sistematik infeksi oleh bakteri, virus, dan jamur pada periode neonatal dengan gejala awal yang bervariasi, dari hanya malas minum, hingga syok septik (Jian, dkk., 2003; Jumah dan Hasan, 2007).

Penelitian kami bertujuan untuk mengetahui profil dan faktor risiko kematian pada neonatus yang mengalami sepsis di RSUD Sukadana Lampung Timur. Dengan mengetahui profil dan faktor risiko ini, diharapkan dapat membantu dalam penanganan, pemberian terapi dan pencegahan sehingga dapat mengurangi jumlah kematian neonatus.

\section{METODE}

Penelitian retrospektif ini dilakukan pada neonatus yang mengalami sepsis. Pasien dirawat dan meninggal di ruang perawatan neonatologi RSUD Sukadana Lampung Timur mulai tanggal 1 Juli 2017 sampai 31 Agustus 2018. Sampel penelitian diambil secara consecutive sampling. Data yang dikumpulkan meliputi jenis kelamin, metode persalinan, usia gestasi, berat badan lahir, usia ibu, tempat persalinan, lama perawatan, profil hematologic, kelainan bawaan, jumlah persalinan, asfiksia, ibu demam intrapartum, ketuban pecah dini lebih dari 18 jam dan awitan sepsis.

Kriteria inklusi adalah semua neonatus dengan sepsis berdasarkan klinis dan laboratorium. Kriteria ekskluasi adalah rekam medis yang tidak lengkap. Karakteristik subjek disajikan secara deskriptif. Data diolah dengan menggunakan program SPSS versi 16 . Uji perbedaan antara kelompok menggunakan $X^{2}$ dan analisis multivariat untuk mengetahui faktor risiko yang bermakna menggunakan regresi logistik. Nilai $p<0,05$ dengan interval kepercayaan 95\% dianggap bermakna secara statistik. Penelitian telah disetujui oleh komite etik RSUD Sukadana Lampung Timur.

\section{HASIL}

Terdapat 55 bayi dengan sepsis yang memenuhi kriteria inklusi pada periode bulan Juli 2017 sampai dengan Agustus 2018. Tidak dilakukan pemeriksaan kultur darah karena belum dapat dilakukan di RSUD Sukadana. Dari 55 bayi tersebut, 25 bayi (45\%) meninggal selama perawatan dan 30 bayi ( $55 \%$ ) hidup dan dapat pulang ke rumah.

Berdasarkan data karakteristik dasar, sebagian besar ibu berusia antara 18-35 tahun (45\%) dengan persalinan tunggal merupakan jumlah persalinan terbanyak (87\%). Sedangkan tempat persalinan meliputi RSUD Sukadana $(36 \%)$, RS lain $(36 \%)$, bidan $(22 \%)$ dan lainnya $(6 \%)$. Rerata lama perawatan bayi sepsis neonatus yang meninggal adalah 6,9 hari. Berdasarkan faktor risiko untuk kematian pada sepsis neonatus, kami mendapatkan jenis kelamin perempuan paling banyak (64\%), lahir tidak spontan $(60 \%)$ dan asfiksia (80\%). Sebagian besar subyek lahir premature (76\%) dan memiliki berat lahir rendah $<2500$ 
gram (80\%). Dari 55 bayi dengan sepsis neonatus, sebagian besar kasus adalah sepsis awitan dini (56\%). Angka kematian dari sepsis neonatus di RSUD Sukadana Lampung

Hasil analisis multivariate menunjukkan bahwa asfiksia, berat lahir rendah dan awitan dini
Timur cukup tinggi yaitu $45 \%$. Angka kematian ini berhubungan dengan asfiksia $(p=0,001)$, berat lahir rendah $(p=0,036)$ dan sepsis awitan dini $(p=0,007) \quad$ (Tabel 2$)$.

merupakan faktor yang berpengaruh terhadap kematian sepsis neonatus (Tabel

Tabel 1. Karateristik sepsis neonatus

\begin{tabular}{|c|c|c|c|}
\hline Karateristik & $\begin{array}{c}\text { Hidup } \\
(n=30)\end{array}$ & $\begin{array}{c}\text { Meninggal } \\
(n=25)\end{array}$ & Total \\
\hline \multicolumn{4}{|l|}{ Usia ibu (tahun) } \\
\hline$\leq 18$ & 4 & 8 & 12 \\
\hline$>18-35$ & 23 & 15 & 38 \\
\hline$>35$ & 3 & 2 & 5 \\
\hline \multicolumn{4}{|l|}{ Persalinan } \\
\hline Tunggal & 29 & 19 & 48 \\
\hline Gemeli & 1 & 4 & 5 \\
\hline Triplet & 0 & 2 & 2 \\
\hline \multicolumn{4}{|l|}{ Tempat bersalin } \\
\hline RSUD Sukadana & 13 & 7 & 20 \\
\hline RS Iain & 11 & 9 & 20 \\
\hline Bidan & 5 & 7 & 12 \\
\hline Lainnya & 1 & 2 & 3 \\
\hline Rerata lama perawatan (hari) & 12,1 & 6,9 & - \\
\hline \multicolumn{4}{|l|}{ Hemoglobin } \\
\hline Anemia & 4 & 18 & 22 \\
\hline Tidak anemia & 26 & 7 & 33 \\
\hline \multicolumn{4}{|l|}{ Leukosit } \\
\hline Leukopenia & 3 & 9 & 12 \\
\hline Leukositosis & 15 & 9 & 24 \\
\hline Normal & 12 & 7 & 19 \\
\hline \multicolumn{4}{|l|}{ Trombosit } \\
\hline Trombositopenia & 9 & 15 & 24 \\
\hline Trombositosis & 1 & 3 & 4 \\
\hline Normal & 20 & 7 & 27 \\
\hline \multicolumn{4}{|l|}{ Kelainan bawaan } \\
\hline Atresia duodeneum & 0 & 2 & 2 \\
\hline Penyakit jantung bawaan & 2 & 4 & 6 \\
\hline Sindrom down & 1 & 1 & 2 \\
\hline Tanpa kelainan bawaan & 27 & 18 & 45 \\
\hline
\end{tabular}

Tabel 2. Faktor risiko kematian sepsis neonatus

\begin{tabular}{|c|c|c|c|c|c|}
\hline \multirow[b]{2}{*}{ Variabel } & \multicolumn{2}{|c|}{ Luaran } & \multirow[b]{2}{*}{$\mathbf{R} \mathbf{R}$} & \multirow[b]{2}{*}{$95 \% \mathrm{CI}$} & \multirow[b]{2}{*}{$\mathbf{P}$} \\
\hline & $\begin{array}{r}\text { Hidup } \\
(n=30)\end{array}$ & $\begin{array}{c}\text { Mati } \\
(n=25)\end{array}$ & & & \\
\hline \multicolumn{6}{|l|}{ Jenis kelamin } \\
\hline Laki-laki & 17 & 9 & 0,63 & $0,34-1,17$ & 0,104 \\
\hline $\begin{array}{l}\text { Perempuan } \\
\text { Cara persalinan }\end{array}$ & 13 & 16 & & & \\
\hline
\end{tabular}




\begin{tabular}{|c|c|c|c|c|c|}
\hline Spontan & 17 & 10 & 0,69 & $0,37-1,26$ & 0,169 \\
\hline Tidak spontan & 13 & 15 & & & \\
\hline \multicolumn{6}{|l|}{ Asfiksia } \\
\hline Ya & 11 & 20 & 3,09 & $1,36-7,05$ & 0,001 \\
\hline Tidak & 19 & 5 & & & \\
\hline \multicolumn{6}{|l|}{ Usia gestasi } \\
\hline Preterm & 15 & 19 & 1,80 & $0,87-3,78$ & 0,072 \\
\hline Aterm & 15 & 6 & & & \\
\hline \multicolumn{6}{|l|}{ Berat lahir(gram) } \\
\hline$<2500$ & 16 & 20 & 2,11 & $0,94-4,73$ & 0,036 \\
\hline$\geq 2500$ & 14 & 5 & & & \\
\hline \multicolumn{6}{|l|}{$\begin{array}{l}\text { Ibu demam } \\
\text { intrapartum }\end{array}$} \\
\hline $\mathrm{Ya}$ & 5 & 8 & 1,38 & $0,77-2,47$ & 0,240 \\
\hline Tidak & 25 & 17 & & & \\
\hline \multicolumn{6}{|c|}{ Ketuban pecah dini } \\
\hline \multicolumn{6}{|c|}{$>18$ jam } \\
\hline $\mathrm{Ya}$ & 10 & 10 & 1.17 & $0,65-2,09$ & 0,408 \\
\hline Tidak & 20 & 15 & & & \\
\hline \multicolumn{6}{|l|}{ Awitan sepsis } \\
\hline Dini & 12 & 19 & 2,45 & $1,16-5,18$ & 0,007 \\
\hline Lanjut & 18 & 6 & & & \\
\hline \multicolumn{6}{|l|}{ Hipoglikemia } \\
\hline Ya & 6 & 5 & 1,01 & $0,49-2,06$ & 0,630 \\
\hline Tidak & 24 & 20 & & & \\
\hline
\end{tabular}

Tabel 3. Uji regresi logistik multivariat

\begin{tabular}{lccc}
\hline \multicolumn{1}{c}{ Variabel } & RR & $\mathbf{9 5 \%} \% \mathbf{~}$ & p \\
\hline Asfiksia & 3,05 & $0,04-0,49$ & 0,002 \\
Berat lahir rendah & 1,72 & $0,09-0,97$ & 0,043 \\
Awitan sepsis dini & 2,51 & $0,07-0,68$ & 0,009 \\
\hline
\end{tabular}

\section{PEMBAHASAN}

Penelitian kami menunjukkan jumlah neonatus perempuan dengan sepsis yang meninggal lebih banyak dibandingkan laki-laki. Hal ini tidak sesuai dengan penelitian Sheikh et al sebelumnya yang mendapatkan angka kematian sepsis neonatus lebih banyak pada laki-laki dibandingkan perempuan (Sheikh, et al., 2010). Sepsis neonatus yang meninggal lebih banyak dijumpai pada bayi berat lahir rendah dan usia gestasi kurang bulan. Penelitian di Nigeria mendapatkan bahwa usia gestasi kurang bulan, berat badan lahir rendah, persalinan yang dilakukan di luar rumah sakit, distress pernafasan, perfusi kulit yang kurang dan kejadian hipoglikemia mempunyai kontribusi terhadap terjadinya kematian pada sepsis neonatus (Waseem, et al., 2005).

Beberapa faktor yang mempengaruhi pada kematian sepsis neonatus kurang bulan dan berat lahir rendah antara lain adalah sistem kekebalan humoral serta seluler yang lemah, penurunan sel darah putih fagositik dan penurunan jumlah produksi sitokin (Trotman, et al., 2006).

Kematian sepsis neonatus dalam penelitian kami adalah 45\%. Angka kematian sepsis neonatus bervariasi antar rumah sakit. Angka kematian sepsis neonatus di Negara berkembang masih cukup tinggi. Di Indonesia, RSCM Jakarta melaporkan kematian sepsis neonatus $14,18 \%$ sedangkan 
Rumah Sakit Moewardi Surakarta melaporkan $40 \%$.

Perbedaan dalam tingkat kematian pada sepsis neontaus disebabkan karena berbagai faktor, antara lain faktor ekonomi, geografis, sosial rasial, penggunaan ventilator, inkubator, akses sentral, jenis mikroorganisme serta penggunaan antibiotika (Rohsiswatmo, 2005; Hafidh, et al., 2007) Pada Rumah Sakit kami, peralatan CPAP dan monitor masih sangat terbatas serta ventilator tidak tersedia. Hasil biakan darah belum dapat dilakukan sehingga pola kuman dan sensitivitas antibiotika belum dapat diketahui. Hal ini menyebabkan pemberian terapi antibitika kausatif menjadi terhambat yang juga mempengaruhi angka kematian.

Penelitian kami menunjukkan bahwa asfiksia, berat lahir rendah dan awitan dini merupakan faktor risiko kematian pada sepsis neonatus. Penelitian Trotman menunjukkan bahwa prematuritas, berat lahir sangat rendah dan jenis kelamin perempuan adalah faktor yang berkaitan dengan luaran buruk (Trotman, dkk., 2006). Sedangkan penelitian di Turki mendapatkan hasil bahwa berat lahir rendah, penggunaan ventilator mekanik serta nutrisi parenteral meningkatkan risiko kematian sepsis neonatus (Turhan, et al., 2015).

Asfiksia merupakan faktor risiko kematian pada bayi, termasuk pada bayi dengan sepsis neonatus. Penelitian sebelumnya menunjukkan bahwa mortalitas akan meningkat pada bayi neonatal sepsis dengan asfiksia dan prematuritas, dibandingkan bayi yang hanya menderita sepsis saja (OR 3,3), asfiksia saja (OR 4,9) atau prematuritas saja (OR 3,5). Keadaan sepsis neonatus yang disertai dengan asfiksia dan prematuritas menyebabkan kerusakan otak terkait dengan disregulasi kemokin dan sitokin dan dapat menyebabkan hipoksia iskemik (Christian, et al.)
Sepsis awitan dini merupakan infeksi perinatal yang terjadi 72 jam pertama kehidupan perinatal dan seringnya disebabkan oleh mikroorganisme inutero atau selama proses persalinan. Penelitian Bulkowstein mengenai sepsis awitan dini menunjukkan hasil lama perawatan rumah sakit yang lebih panjang dan angka kematian yang lebih tinggi dibandingkan sepsis awitan lanjut $(20 \%$ vs $5,3 \%$, $p=0,0002)$ dengan mikroorganisme penyebab terbanyak adalah E. Coli dan Streptocococcus grup $b$ hemoliticus (Bulkowstein, et al., 2016).

Keterbatasan penelitian kami antara lain tidak memasukkan variable lain yang mungkin dapat mempengaruhi tingginya angka kematian sepsis neonatus, seperti riwayat penyakit ibu yang diderita selama hamil. Diperlukan penelitian lebih lanjut mengenai faktor risiko yang terkait dengan mortalitas.

\section{KESIMPULAN}

Tingkat kematian sepsis neonatus 45\%. Asfiksia, berat lahir rendah dan kejadian sepsis awitan dini merupakan faktor risiko kematian pada sepsis neonatus. Diperlukan pencegahan, strategi serta tatalaksana komprehensif untuk mengurangi tingkat mortalitas pada sepsis neonatus.

\section{DAFTAR PUSTAKA}

Ayoniyi DO, Udo SJ, Oguntibeju OO. (2009). An epidemiological survey of neonatal sepsis in a hospital in Western Nigeria. African J Microbiol Res. 3:3859.

Bulkowstein S, Ben Shimol S, Givon Lavi N, Melamed R, Shany E, Greenberg D. (2016). Comparison of early onset sepsis and community acquired late onset sepsis in infants less than 3 months of age. BMC Pediatrics. 16*82):1-8.

Christian P, Darmstadt G, Wu L, et al. The impact of maternal micronutrient supplementation 
on early neonatal morbidity in rural nepal: A randomized, controlled community trial. Arch Dis Child. manuscript in press.

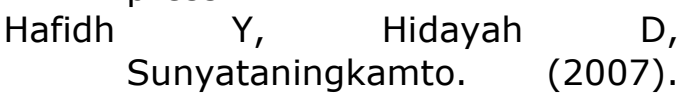
Jain NK, Jain VM, Maheshwari S. (2003). Clinical profile of neonatal sepsis. Kathmandu Univ Med J. 1:117-20.

Jumah DS, Hassan MK. (2007). Predictor of mortality outcome in neonatal sepsis. The Medical Journal of Basrah University (MJBU). 25:11-8.

Rohsiswatmo R. (2005). Kontroversi diagnosis sepsis neonatorum. Dalam: Hegar B, Trihono PP, Ifran $\mathrm{EB}$, penyunting. Update in neonatal infection. Pendidikan Kedokteran Berkelanjutan IImu Kesehatan Anak XLVIII, Departemen IImu Kesehatan Anak FK UI/RSCM Jakarta. Jakarta: Departemen ilmu kesehatan anak FKUIRSCM. h. 32-43.
Factors affecting mortality of neonatal sepsis in Moewardi Hospital Surakarta. Paediatri Indonesia. 47:74-7.

Sheikh AM, Javed T, Afzal MF, Sheikh CA. (2010). Course and complications of early onset neonatal sepsis: a descriptive study. Annals. 16: 307-10.

Trotman $H$, Bell $Y$, Thame $M$, Nicholson AM, Barton $M$. (2006). Predictor of poor outcome in neonates with bacterial sepsis admitted to the University Hospital of the West Indies. West Indian Med $\mathrm{J}$. 55:80-4.

Turhan E, Gursoy T, Ovali F. (2015). Factors which affected mortality in neonatal sepsis. Turk Pediatri Arc. 50:170-5.

Waseem R, Shah AA, Khan MQ, Qureshi W. (2005). Indicators of early outcome in neonatal sepsis. Biomed. 21:117-20. 